${ }^{1}$ Neuroendocrine Unit, Division of Endocrinology and Metabolism, Hospital das Clinicas, Faculdade de Medicina, Universidade de São Paulo (HC-FMUSP), São Paulo, SP, Brazil

2 Department of Pathology, FMUSP, São Paulo, SP, Brazil ${ }^{3}$ Laboratório de Investigação Médica em Reumatologia (LIM-17), FMUSP, São Paulo, SP, Brazil

Correspondence to: Marcello D. Bronstein Unidade de Neuroendocrinologia Divisão de Endocrinologia e Metabologia,

Hospital das Clínicas,

Faculdade de Medicina

Universidade de São Paulo

Av. Dr. Eneas de Carvalho, 255

$7^{\circ}$ andar, sala 7037, Instituto Central 05403-000 - São Paulo, SP, Brazil

mdbronstein@uol.com.br

\section{An intrasellar germinoma with normal tumor marker concentrations mimicking primary lymphocytic hypophysitis}

\author{
Germinoma intrasselar com marcadores tumorais \\ normais mimetizando hipofisite linfocítica primária
}

\author{
Mariana F. Guzzo', Cristina B. Formiga Bueno', Thiago T. \\ Amancio'2, Sergio Rosemberg', Cleonice Bueno ${ }^{3}$, Edson L. \\ Arioli' ', Andrea Glezer', Marcello D. Bronstein'
}

\begin{abstract}
SUMMARY
Intracranial germinomas (GE) are malignant neoplasms most commonly found in the suprasellar region, which may cause anterior and particularly posterior pituitary hormone deficits with central diabetes insipidus (DI). Differential diagnosis of pituitary stalk thickening includes granulomatous, inflammatory, infectious, and neoplastic lesions. Although careful analysis of clinical, laboratory, and imaging findings may facilitate the diagnosis, transsphenoidal biopsy is indicated to confirm the disease, as the correct diagnosis directs the appropriate treatment. Arq Bras Endocrinol Metab. 2013;57(7):566-70
\end{abstract}

\section{SUMÁRIO}

Germinomas intracranianos (GE) são neoplasias malignas comumente na região suprasselar, podendo causar deficiência hormonal da hipófise anterior, em particular da hipófise posterior, com diabetes insípido central (DI). Entre os diagnósticos diferenciais do espessamento de haste hipofisária, incluem-se doenças granulomatosas, inflamatórias, infecciosas e neoplásicas. Embora as avaliações clínica, laboratorial e a ressonância magnética selar sugiram o diagnóstico, a biópsia transesfenoidal está indicada para confirmação, visto que o diagnóstico correto direciona o tratamento. Arq Bras Endocrinol Metab. 2013;57(7):566-70

\section{INTRODUCTION}

$\mathrm{I}$ ntracranial germinomas (GE) are malignant neoplasms that most likely arise from primitive germ cells that failed to migrate to the genital crest during embryonic development (1). They represent about $3.4 \%$ of all primary intracranial tumors, predominantly affect pre-pubertal children, and are more often localized in the pineal gland or suprasellar region, although bifocal lesions have also been described $(1,2)$. Most commonly, they cause anterior (mainly GH deficiency) and particularly posterior pituitary hormone deficits with central diabetes insipidus (DI) (1).

Other diseases of neoplastic, granulomatous, infectious and inflammatory origin could be difficult to dif- ferentiate from GE, because of the similar clinical, imaging and pathological features. In order to elucidate the etiopathogenesis in patients with difficult differential diagnosis, a transsphenoidal biopsy is indicated (1).

Regarding the proper approach, corticosteroids for lymphocytic hypophysitis ( $\mathrm{LH}$ ) and radiotherapy (RaT) plus chemotherapy (ChT) for GE (2), a case of GE mimicking $\mathrm{LH}$ is presented.

\section{CASE REPORT}

\section{History and clinical examination}

After one year of an uneventful delivery, a 24 year-old patient presented amenorrhea (even after breastfeeding 
was stopped), polyuria, polydipsia, fatigue, galactorrhea, dry skin, and hair loss. She described a pulsatile headache since adolescence. Weight and body mass index (BMI) were $63.2 \mathrm{~kg}$ and $24.5 \mathrm{~kg} / \mathrm{m}^{2}$, respectively. Her medical and family history was unremarkable. Physical and neurological examination revealed no abnormality. Biochemical evaluation was normal. Regarding basal hormonal evaluation, she presented hyperprolactinemia (prolactin: $50 \mathrm{ng} / \mathrm{mL}$ - normal range (NR): 2.0-15.0 ng/mL), hypogonadotropic hypogonadism, secondary hypothyroidism (fT4: $0.56 \mu \mathrm{U} / \mathrm{mL}-\mathrm{NR}$ : $0.70-1.50 \mathrm{ng} / \mathrm{mL}$; TSH: $2.3 \mu \mathrm{U} / \mathrm{mL}-\mathrm{NR}: 0.40$ $4.5 \mu \mathrm{U} / \mathrm{mL}$ ), and low basal serum cortisol (cortisol 8 am: $7.5 \mu \mathrm{g} / \mathrm{dL}$ - NR: 5-25 $\mu \mathrm{g} / \mathrm{dL}$ ). Central DI was diagnosed based on clinical presentation and response to desmopressin (DDAVP) on the water deprivation test, leading to oral DDAVP treatment. She was also replaced with L-T4 and hydrocortisone acetate. Serum and spinal cerebral fluid (CSF) tumor markers (alphafetoprotein and $\beta$-HCG) were negative. Physical examination, chest $\mathrm{x}$-ray, blood angiotensin-converting enzyme (ACE) was measured, and a PPD test (Tuberculin Purified Protein Derivative Test) excluded sarcoidosis and tuberculosis, respectively. Other diagnostic workup included a skeletal survey to rule out histiocytosis. Several serum autoimmune antibodies were positive: anti-thyroid, antinuclear and anti-pituitary (APA) an- tibodies were positive. The detection of anti-pituitary antibodies was performed by indirect immunofluorescence in tissue sections of human cadaveric pituitary glands based on a research protocol of the University of Sao Paulo Medical School.

Sellar magnetic resonance imaging (sellar MRI) depicted a supraselar mass extending to the posterior pituitary with normal sellar space, leading to a diffuse thickening of the pituitary stalk (Figure IA and IB). Optic chiasm was normal. Invasion of the cavernous sinus was not evident.

Despite the clinical evidence pointing to lymphocytic hypophysitis, a pituitary biopsy through transsphenoidal route was performed in order to rule-out other causes and, therefore, to choose the appropriate therapy. Pathological examination showed a biphasic population of mature small lymphocytes and large neoplastic cells with abundant clear cytoplasm, round central nuclei and prominent nucleoli (Figure 2A). Immunohistochemistry (IHC) was positive for placental alkaline phosphatase (PLAP) (Figure 2B) and c-kit protein (CD 117 ) in the neoplastic large cells (not shown) confirmed the diagnosis of an intrasellar GE. Immune markers also revealed a population of B-lymphocytes (CD 20 positive - Figure 2C) and T-lymphocytes (CD 3 positive Figure 2D). The patient was referred to treatment with ChT and RaT with clinical improvement.
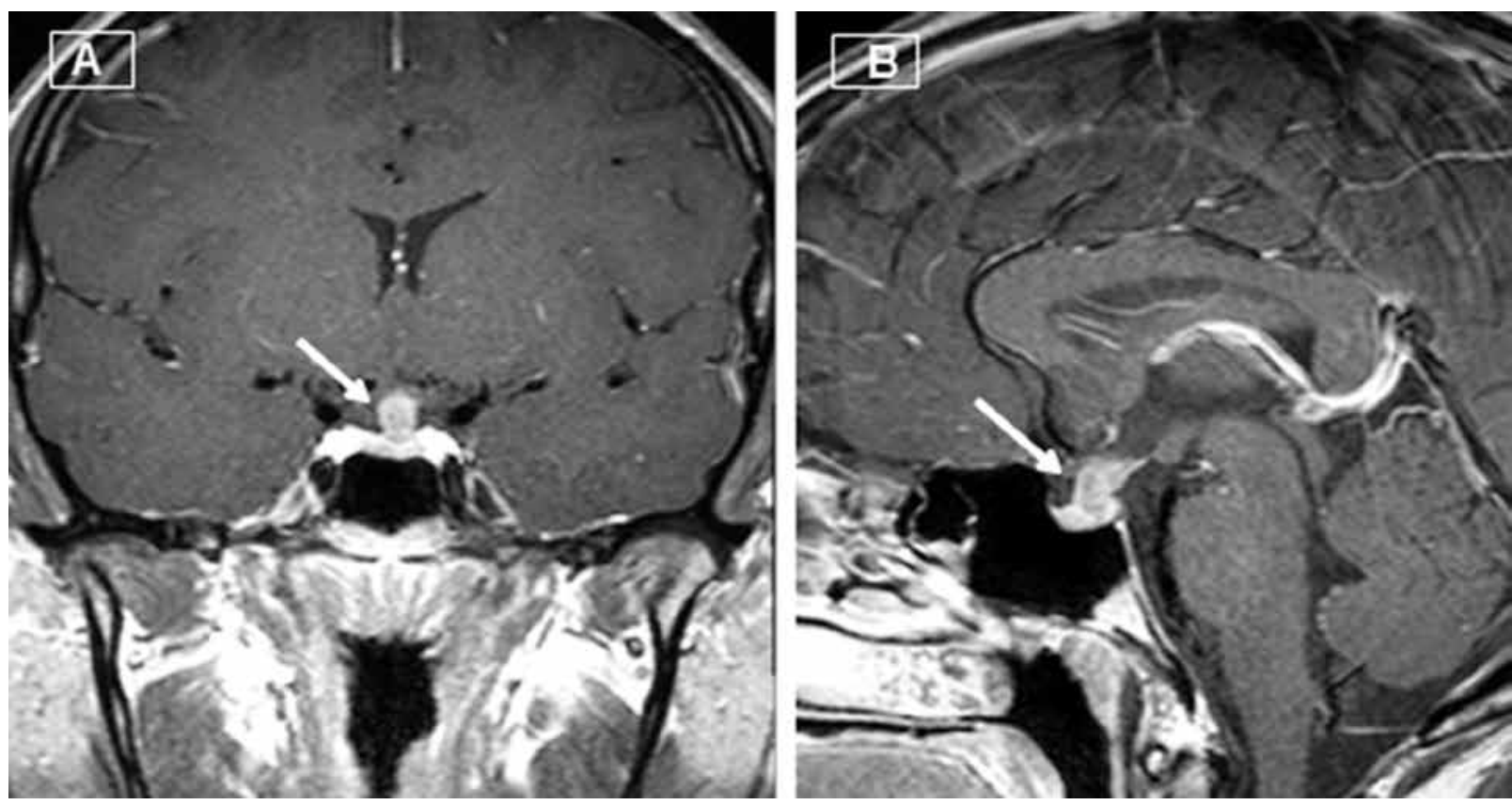

Figure 1. Suprasellar mass lesion reaching the posterior pituitary, leading to stalk thickening with normal sella (white arrow); $T 1$ - weighted images in coronal (A) and sagittal (B) planes after paramagnetic contrast media administration are shown. 


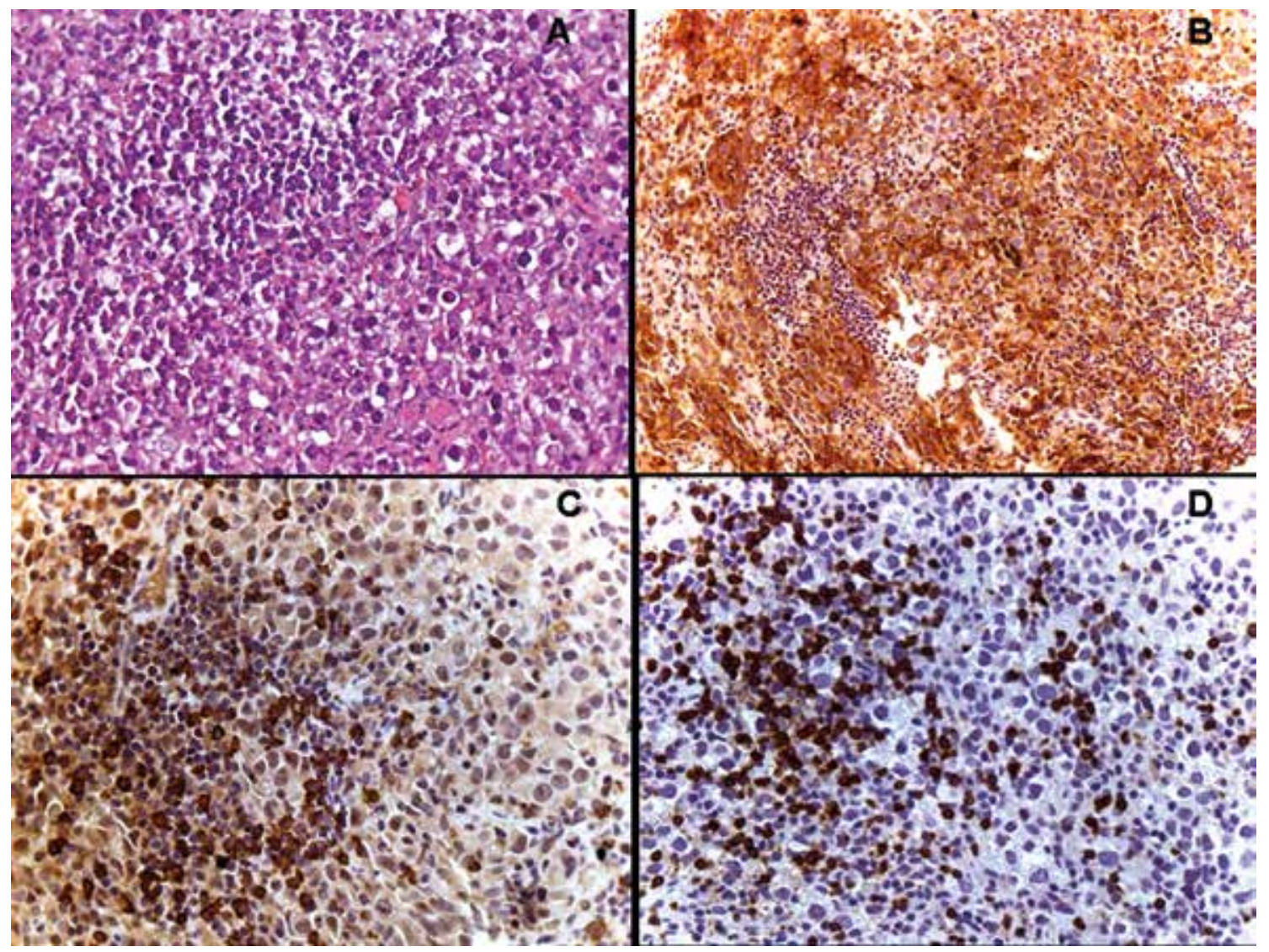

Figure 2. (A) Large tumor cells with round nuclei and abundant clear cytoplasm. Presence of moderate lymphocytic infiltrate. (H \& E, 200X); (B) Tumor cells showing PLAP immunoreactivity; (C) Presence of B-lymphocytes (CD 20 positive); (D) Presence of T-lymphocytes (CD3 positive).

\section{DISCUSSION}

This study deals with the difficulties in diagnosing pituitary stalk thickening lesions, reporting a patient with a typical clinical and laboratorial picture of $\mathrm{LH}$ in which the final histopathological diagnosis was GE.

The differential diagnosis of masses affecting the pituitary stalk is broad and includes inflammatory and infectious diseases, germ cell tumors, gliomas, meningioma, metastatic tumors, and vascular lesions (3).

$\mathrm{LH}$ is a rare entity with estimated incidence of one case in nine million persons-year characterized by pituitary and/or stalk autoimmune inflammation. The average age at diagnosis is 34.5 years in females and 44.7 years in males. Lymphocytic adenohypophysitis (LAH) is strongly associated with pregnancy, $57 \%$ of cases occurring during gestation or in the postpartum period. This could be related to a pituitary antigens presentation to the immune system, probably due to lactotroph hyperplasia and increase in pituitary blood flow (4).

Clinical presentation of LAH is variable and includes symptoms related to mass compression of sellar neigh- boring regions (optic chiasm, cavernous sinus), hypopituitarism, and hyperprolactinemia. Its clinical suspicion should be raised if the degree of hypopituitarism conflicts with the appearance of pituitary gland in imaging exams, and rapidly installation of hormonal deficiencies, mainly in the corticotrophic axis, in women in the puerperal period. Central DI can occur if posterior pituitary or pituitary stalk are involved. Sellar MRI routinely shows homogeneous enhancement of the entire gland. The association with others autoimmune diseases happens in $20 \%$ of the cases, mostly with Hashimoto's thyroiditis (5).

The current methods used for APA evaluation are not commercially available and their specificity and sensitivity must be improved in order to permit an accurate diagnosis in LH. Lupi and cols. described about $50 \%$ of sensibility of APA in histologically-proven LH. However, APA were also found in other pituitary diseases, such as pituitary adenoma and primary empty sella, and other autoimmune endocrine conditions, such as Hashimoto's thyroiditis, Grave's disease, and post-partum thyroiditis (6). 
Table 1. Ten cases of germinoma mimicking clinically lymphocytic hypophysitis described in the literature

\begin{tabular}{|c|c|c|c|c|c|c|c|c|c|c|}
\hline Case & Age & Sex & Clinical picture & $\begin{array}{l}\text { Hormonal } \\
\text { evaluation }\end{array}$ & $\begin{array}{l}\text { Thickening of } \\
\text { pituitary stalk } \\
\text { in sellar MRI }\end{array}$ & APA & $\begin{array}{l}\text { Mononuclear } \\
\text { and } \\
\text { lymphocytic } \\
\text { infiltrate }\end{array}$ & $\begin{array}{l}\text { Serum } \\
\text { Tumoral } \\
\text { markers }\end{array}$ & IHC & $\begin{array}{c}\text { Initial } \\
\text { treatment }\end{array}$ \\
\hline $\begin{array}{l}\text { Ozbey and cols., } \\
2006 \text { (1) }\end{array}$ & 24 & Female & Headache & Panhyp & $\begin{array}{l}\text { Yes }+ \\
\text { intrasellar mass }\end{array}$ & ND & ND & $\beta-H C G$ & PLAP & GCE \\
\hline $\begin{array}{l}\text { Gutenberg and } \\
\text { cols., } 2011 \text { (2) }\end{array}$ & 11 & Female & $\begin{array}{l}\text { Blurred vision, } \\
\text { fatigue, polyuria, } \\
\text { polydipsia and } \\
\text { low stature }\end{array}$ & Panhyp + DI & $\begin{array}{l}\text { No and intra } \\
\text { and suprasellar } \\
\text { mass with } \\
\text { posterior } \\
\text { extension }\end{array}$ & Negative & Yes & Negative & CD79 CD3 & GCE \\
\hline $\begin{array}{l}\text { Saborowski and } \\
\text { cols., } 2007 \text { (12) }\end{array}$ & 12 & Female & Low stature & Panhyp + DI & yes & ND & Yes & ND & $\mathrm{Nd}$ & GCE \\
\hline $\begin{array}{l}\text { Houdouin and } \\
\text { cols., } 2003 \text { (13) }\end{array}$ & 13 & Male & $\begin{array}{l}\text { Visual field } \\
\text { defects }\end{array}$ & Panhyp + DI & yes & ND & Yes & ND & $\begin{array}{l}\text { PLAP } \\
\text { CD117 }\end{array}$ & Surgery \\
\hline $\begin{array}{l}\text { Houdouin and } \\
\text { cols., } 2003 \text { (13) }\end{array}$ & 21 & Male & $\begin{array}{l}\text { Visual fields } \\
\text { defects, polyuria }\end{array}$ & Panhyp + DI & yes & ND & Yes & ND & $\begin{array}{l}\text { PLAP } \\
\text { CD117 }\end{array}$ & Surgery \\
\hline $\begin{array}{l}\text { Fehn and cols., } \\
1999 \text { (14) }\end{array}$ & 12 & Female & Polyuria & Panhyp + DI & $\begin{array}{l}\text { Yes }+ \\
\text { intrasellar mass }\end{array}$ & ND & Yes & ND & $\mathrm{Nd}$ & GCE \\
\hline $\begin{array}{l}\text { Terasaka and } \\
\text { cols., } 2012 \text { (9) }\end{array}$ & 40 & Female & $\begin{array}{l}\text { Headache, } \\
\text { diplopia, } \\
\text { amenorrhea }\end{array}$ & Panhyp + DI & $\begin{array}{l}\text { Yes + intra and } \\
\text { suprasellar } \\
\text { mass }\end{array}$ & ND & $\begin{array}{l}\text { Yes and marked } \\
\text { fibrous tissue }\end{array}$ & PLAP & $\begin{array}{l}\text { CD43; } \\
\text { CD45R0; } \\
\text { CD20 }\end{array}$ & GCE \\
\hline $\begin{array}{l}\text { Mikami-Terao } \\
\text { and cols., } 2006 \\
\text { (10) }\end{array}$ & 13 & Female & $\begin{array}{l}\text { Headache and } \\
\text { pubertal arrest }\end{array}$ & Panhyp + DI & $\begin{array}{l}\text { Yes + intra and } \\
\text { suprasellar } \\
\text { mass }\end{array}$ & Positive & Yes & PLAP & $\begin{array}{l}\text { CD20; } \\
\text { CD45R0; } \\
\text { CD3; CD5; } \\
\text { CD45R0 }\end{array}$ & GCE \\
\hline $\begin{array}{l}\text { Torremocha and } \\
\text { cols., } 2002(15)\end{array}$ & 45 & Male & $\begin{array}{l}\text { headache and } \\
\text { extraocular } \\
\text { muscle palsy }\end{array}$ & $\begin{array}{l}\text { FSH and LH } \\
\text { deficiencies }\end{array}$ & $\begin{array}{l}\text { Intrasellar mass } \\
\text { extending in to } \\
\text { rigth cavernous } \\
\text { sinus }\end{array}$ & ND & Yes & $\begin{array}{l}\beta \text {-HCG in } \\
\text { CSF }\end{array}$ & $\begin{array}{l}\text { PLAP } \\
\text { Vimentin }\end{array}$ & GCE \\
\hline $\begin{array}{l}\text { Endo and cols., } \\
2002 \text { (16) }\end{array}$ & 12 & Male & $\begin{array}{l}\text { Low stature, } \\
\text { fadiga, } \\
\text { bitemporal } \\
\text { hemianopsia }\end{array}$ & Panhyp + DI & $\begin{array}{l}\text { Intra and } \\
\text { suprasellar } \\
\text { mass extension } \\
\text { to right } \\
\text { cavernous } \\
\text { sinus }\end{array}$ & ND & $\begin{array}{l}\text { Yes with } \\
\text { multinucleated } \\
\text { giant cells }\end{array}$ & Negative & PLAP & Surgery \\
\hline
\end{tabular}

CSF: cerebral spinal fluid; DI: diabetes insipidus; Panhyp: panhypopituitarism; APA: antipituitary antibodies; ND: not done; Nd: not described; PLAP: placental alkaline phosphatase; IHC: immunohistochemistry; GCE: glucocorticoid.

The definitive diagnosis of LH depends on histopathological evaluation. Nevertheless, a presumptive diagnosis could be done in a typical case, and a therapeutic approach should be based on the grade of suspicious and clinical manifestations of $\mathrm{LH}(7)$. In the present case, we would like to emphasize the importance of histopathological confirmation since pitfalls in diagnosis may occur.

GE are rare lesions, affecting predominantly pre-pubertal children and are more often localized in the pineal gland and/or in suprasellar region. Clinically, they are present as a triad of central DI, hypopituitarism, and visual disturbances, which could mask other lesions that affect sellar region. This form of brain neoplasm is a highly curable with RaT and ChT (8).

To date, about ten cases (Table 1) of LH clinically mimicking GE have been reported. In most of them, the initial diagnosis was $\mathrm{LH}$, and treatment with corticosteroids was prescribed. The unfavorable clinical follow-up followed by pituitary biopsy was critical for diagnosis. In most cases, the histological diagnosis of GE is not difficult due to its typical pathological finding, the "two-cell pattern" (9).

GE are highly immunogenic tumors and frequently have infiltrating lymphocytes into the tumor (10), but 
the finding of APA is rare. Besides, APA positivity in the reported patient harbored others autoimmune disorders, such as Hashimoto's thyroiditis and positive antinuclear antibody $(7,11)$.

In conclusion, diffuse lymphocytic infiltration in sellar masses and pituitary antibodies do not always indicate a diagnosis of $\mathrm{LH}$, even with its typical clinical and radiological features. However, the precise diagnosis can only be obtained with histological assessment in order to rule out others diseases, such as GE.

Disclosure: no potential conflict of interest relevant to this article was reported.

\section{REFERENCES}

1. Ozbey N, Sencer A, Tanyolac S, Kurt R, Sencer S, Bilgic B, et al. An intrasellar germinoma with normal cerebrospinal fluid betaHCG concentrations misdiagnosed as hypophysitis. Hormones (Athens). 2006;5(1):67-71.

2. Gutenberg A, Bell JJ, Lupi I, Tzou SC, Landek-Salgado MA, Kimura $\mathrm{H}$, et al. Pituitary and systemic autoimmunity in a case of intrasellar germinoma. Pituitary. 2011;14(4):388-94.

3. Glezer A, Bronstein MD. Approach to the patient with persistent hyperprolactinemia and negative sellar imaging. J Clin Endocrinol Metab. 2012;97(7):2211-6.

4. Caturegli P, Newschaffer C, Olivi A, Pomper MG, Burger PC, Rose NR. Autoimmune hypophysitis. Endocr Rev. 2005;26(5):599614.

5. Caturegli P, Lupi I, Landek-Salgado M, Kimura H, Rose NR. Pituitary autoimmunity: 30 years later. Autoimmun Rev. 2008;7(8):631-7.
6. Lupi I, Manetti L, Raffaelli V, Lombardi M, Cosottini M, lannelli A, et al. Diagnosis and treatment of autoimmune hypophysitis: a short review. J Endocrinol Invest. 2011;34(8):e245-52.

7. Glezer A, Bronstein MD. Pituitary autoimmune disease: nuances in clinical presentation. Endocrine. 2012;42(1):74-9.

8. Jensen AW, Laack NN, Buckner JC, Schomberg PJ, Wetmore CJ, Brown PD. Long-term follow-up of dose-adapted and reducedfield radiotherapy with or without chemotherapy for central nervous system germinoma. Int $\mathrm{J}$ Radiat Oncol Biol Phys. 2010;77(5):1449-56.

9. Terasaka S, Kawabori M, Kobayashi H, Murata J, Kanno H,Tanaka S, et al. Neurohypophyseal germinoma with abundant fibrous tissue. Brain Tumor Pathol. 2012;29(1):58-62.

10. Mikami-Terao Y, Akiyama M, Yanagisawa T, Takahashi-Fujigasaki J, Yokoi K, Fukuoka K, et al. Lymphocytic hypophysitis with central diabetes insipidus and subsequent hypopituitarism masking a suprasellar germinoma in a 13-year-old girl. Childs Nerv Syst. 2006;22(10):1338-43.

11. Glezer A, Paraiba DB, Bronstein MD. Rare sellar lesions. Endocrinol Metab Clin North Am. 2008;37(1):195-211.

12. Saborowski $O$, Radü $E$, Medelowitsch A, Tolnay M, Kirsch E. Suprasellar germinoma masked by lymphocytic hypophysitis: a case report. Clin Neuroradiol. 2007;17:259.

13. Houdouin L, Polivka M, Henegar C, Blanquet A, Delalande O, Mikol J. [Pituitary germinoma and lymphocytic hypophysitis: a pitfall. Report of two cases]. Ann Pathol. 2003;23(4):349-54.

14. Fehn $M$, Bettendorf $M$, Lüdecke DK, Sommer C, Saeger W. Lymphocytic hypophysitis masking a suprasellar germinoma in a 12-year-old girl -- a case report. Pituitary. 1999;1(3-4):303-7.

15. Torremocha F, Hadjadj S, Menet E, Kas A, Bourgeois H, Levillain $P$, et al. [Pituitary germinoma presenting as a pseudotumoral lymphocytic hypophysitis in a man]. Ann Endocrinol (Paris). 2002;63(1):13-7.

16. EndoT, KumabeT, Ikeda H, Shirane R, YoshimotoT. Neurohypophyseal germinoma histologically misidentified as granulomatous hypophysitis. Acta Neurochir (Wien). 2002;144(11):1233-7. 